\title{
Respiratory System Findings Sequence Number
}

National Cancer Institute

\section{Source}

National Cancer Institute. Respiratory System Findings Sequence Number. NCI

Thesaurus. Code C124002.

An identifier that describes the relative position of respiratory system findings data within a series. 